\title{
Preparation of Photoactivable Amino Acid Derivatives
}

\author{
Jean-Luc Débieux and Christian G. Bochet* \\ Department of Chemistry, University of Fribourg, 9 Chemin du Musée, CH-1700 Fribourg, Switzerland
}

christian.bochet@unifr.ch

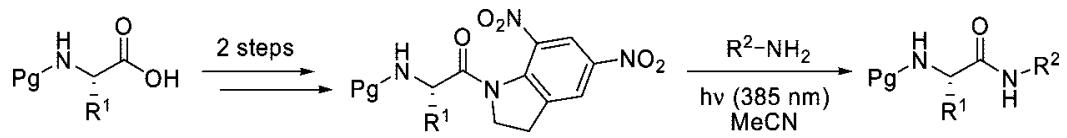

A range of $N$-protected- $\alpha$-amino acyl-5,7-dinitroindolines $3 \mathbf{a}-\mathbf{z}$ were prepared in good yields from commercially available $N$-protected- $\alpha$-amino acids $1 \mathbf{a}-\mathbf{z}$ by a two-step sequence of acylation and intramolecular amide $N$-arylation. Subsequent photochemical acylation of the $N$-protected- $\alpha$-amino acyl5,7-dinitroindolines 3e,g,r afforded the corresponding $N$-protected- $\alpha$-amino acid amides $22 \mathbf{e}, \mathbf{g}, \mathbf{r}(77-92 \%)$ under mild conditions. All these reactions occurred with complete retention of chirality as evidenced by NMR analysis. This scheme provides an attractive and alternative method to the conventional acylation of $\alpha$-amino acids, especially in cases where the amide bond needs to be formed without the use of a coupling reagent.

\section{Introduction}

$\alpha$-Amino amides, the fundamental functional group in naturally occurring peptides and proteins, are important synthetic targets, as they have been claimed to show anti-inflammatory, ${ }^{1,2}$ antibacterial, ${ }^{3}$ anticonvulsant, ${ }^{4}$ cerebroprotective, and anti-HIV activity, ${ }^{5,6}$ and have been utilized as local anesthetics, ${ }^{7}$ analgesics, ${ }^{8}$ and melanocortin agonists. ${ }^{9}$

Many methods have been developed for the formation of amide bonds, most of them involving the reaction between an activated carboxylic acid as an electrophile and a free amine as a nucleophile. ${ }^{10}$ However, many of these reactions have various drawbacks, extensively described by Katrizky et al. ${ }^{11}$ A desirable feature for this reaction would be a neutral medium, mild temperature, great tolerance toward nucleophiles other than amines, and the possibility of mixing both reactants and

(1) Chemistry and Biochemistry of Amino Acids; Barrett G. C., Ed.; Chapman and Hall: London, UK, 1985.

(2) Marcincal-Lefebvre, A.; Gesquiere, J. C.; Lemer, C.; Dupuis, B. J. Med. Chem. 1981, 24, 889.

(3) Joshi, K. C.; Pathak, V. N.; Jain, S. K. Pharmazie 1980, 35, 677.

(4) (a) Bachir, M.; Riffaud, J.-P.; Lacolle, J.-Y.; Lemoine, J.; De Almeida, A.; Houziaux, P.; Danree, B. Eur. J. Med. Chem. 1990, 25, 71. (b) Chiesi, P.; Ventura, P.; Delcanale, M.; De Fanti, R.; Armani, E.; Villetti, G.; Pietra, C. PCT Int. Appl. WO 9803472, 1998.

(5) Oshiro, Y.; Sakurai, Y.; Tanaka, T.; Kikuchi, T.; Hirose, T.; Tottori, K. J. Med. Chem. 1991, 34, 2014.

(6) Song, Y.; et al. Bioorg. Med. Chem. 2002, 10, 1263-1273.

(7) Dullenkopf, A.; Borgeat, A. Anaesthesist 2003, 52, 329.

(8) Salvati, P.; Veneroni, O.; Maj, R.; Fariello, R.; Benatti, L. Int. Pat. WO 03020273, 2003.

(9) Poindexter, G. S.; Luo, G.; Chen, L. U. S. Pat. 20030232807, 2003.

(10) Montalbetti, C. A. G. N.; Falque, V. Tetrahedron 2005, 61, 1082710852 .

(11) Katritzky, A. R.; He, H.-Y.; Suzuki, K. J. Org. Chem. 2000, 65, 8210. triggering the process at the appropriate time. The photoacylation reaction fulfills most of these requirements. It was developed a few decades ago by Amit and Patchornik, ${ }^{12}$ with the introduction of the 5-bromo-7-nitroindolinyl (Bni) photoactivable leaving group, initially designed to block a carboxylic function through the formation of its amide derivative, the $\mathrm{N}$-acyl-5-bromo-7nitroindoline. Irradiation at $420 \mathrm{~nm}$ or below activates the acyl function toward nucleophilic attack. Later, the Bni group was employed both to mask and to activate a terminal carboxylic function in order to assemble two peptide units. ${ }^{13}$ We recently pointed out several advantages of the 5,7-dinitroindolinyl (Dni) group over its Bni analogue; ${ }^{14}$ in particular shorter reaction times (up to a factor of 4) and a significantly higher quantum yield for its photocleavage. ${ }^{15}$ In this context, we elaborated a convenient method, using $N$-acyl-5,7-dinitroindolines as more efficient agents for the photochemical acylation of amines ${ }^{14}$ and alcohols ${ }^{16}$ under exceptionally mild and practical conditions. We now extend the $N$-acyl-5,7-dinitroindoline chemistry to prepare stable $N$-protected- $\alpha$-amino acyl-5,7-dinitroindolines $\mathbf{3 a}-\mathbf{z}$ derived from $N$-protected- $\alpha$-amino acids $\mathbf{1 a}-\mathbf{z}$ and their utilization in the synthesis of $N$-protected- $\alpha$-amino acid amides 22e,g,r by photochemical acylation.

(12) (a) Amit, B.; Patchornik, A. Tetrahedron Lett. 1973, 24, 2205-2208. (b) Amit, B.; Ben-Efraim, D. A.; Patchornik, A. J. Am. Chem. Soc. 1976, 98, 843-844.

(13) Pass, S.; Amit, B.; Patchornik, A. J. Am. Chem. Soc. 1981, 103, 76747675 .

(14) Helgen, C.; Bochet, C. G. Synlett 2001, 1968-1970.

(15) Adams, S. R.; Kao, J. P. Y.; Tsien, R. Y. J. Am. Chem. Soc. 1989, 111, 7957-7968

(16) Débieux, J.-L.; Cosandey, A.; Helgen, C.; Bochet, C. G. Eur. J. Org. Chem. 2007, 207, 3-2077. 
SCHEME 1. Attempt of Direct Acylation of Cbz-L-Leu-OH with 5,7-Dinitroindoline

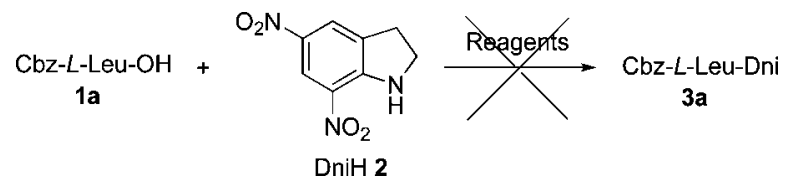

\section{Results and Discussion}

I. Preparation of $N$-Protected- $\alpha$-Amino Acyl-5,7-Dinitroindolines. Our first approach to prepare $N$-protected- $\alpha$-amino acyl5,7-dinitroindolines $\mathbf{3} \mathbf{a}-\mathbf{z}$ was a direct acylation between commercially available $N$-protected- $\alpha$-amino acids $\mathbf{1 a}-\mathbf{z}$, such as Cbz- $L$-Leu-OH (1a), and 5,7-dinitroindoline (DniH) (2) (Scheme 1). DniH is easily synthesized in 3 steps from indoline by successive reactions of acetylation, dinitration, and deacetylation in a $58 \%$ overall yield. ${ }^{17}$

Different classical methods for direct acylation proved unsuccessfull due to the very poor nucleophilicity of the amine group of 5,7-dinitroindoline (DniH, 2). Amino acid halides, which are generated in situ and frequently used as intermediates for peptide coupling, ${ }^{18}$ gave no acylation product, even when used in conjunction with a Lewis acid to activate the acid halide. Standard coupling reagents for peptide bond formation such as EDC/DMAP, BOP, DCC/HOBt, HBTU, or $\mathrm{POCl}_{3} /$ pyridine were also inefficient. ${ }^{19}$ Deprotonation of DniH (2) with strong bases like $\mathrm{NaH}$ or $n$-BuLi and successive reaction with the pivaloyl anhydrides or fluorides of amino acids, or with the amino acid themselves in the presence of coupling reagents such as EDC/ DMAP, was unsuccessful. Neither the polymer-supported $\mathrm{Mu}-$ kaiyama reagent, ${ }^{20}$ which is a useful coupling reagent for the synthesis of esters and amides, nor the anhydride intermediate, nor the use of diphosphorus tetraiodide $\left(\mathrm{P}_{2} \mathrm{I}_{4}\right){ }^{21}$ as a mild coupling agent, resulted in acylation. Even the original attachment method developed by Patchornik, ${ }^{13}$ which involves heating a mixture of 5-bromo-7-nitroindoline and $N$-protected- $\alpha$-amino acids with thionyl chloride in toluene at $40-70{ }^{\circ} \mathrm{C}$ for several hours, failed for DniH (2), obviously due to the presence of two strong electron-withdrawing groups on the aromatic part. To circumvent that problem, our next approach was to prepare $N$-protected- $\alpha$-amino acyl-5,7-dinitroindolines $\mathbf{3 a}-\mathbf{z}$ via an indirect acylation. Again, neither the formation of $\mathrm{N}$-(protected$\alpha$-amino acyl)benzotriazoles, developed by Katritzky ${ }^{22}$ as acylating agents to create peptide bonds, nor the synthesis of $N$-(protected- $\alpha$-amino acyl)indolines, were able to form the corresponding $N$-protected- $\alpha$-amino acyl-5,7-dinitroindolines $\mathbf{3 a}-\mathbf{z}$.

To avoid having a very poor nucleophile for the acylation, a new strategy was envisioned. The goal was to prepare a phenylethylamine derivative such as $\mathbf{4 - 7}$, which could be easily acylated with different $N$-protected- $\alpha$-amino acids $1 \mathbf{a}-\mathbf{z}$, due to the nucleophilic and sterically undemanding primary amine. After subsequent cyclization by intramolecular Buchwald-Hartwig amide $\mathrm{N}$-arylation, ${ }^{23} \mathrm{~N}$-protected- $\alpha$-amino acyl-5,7-dinitroindolines $3 \mathbf{a}-\mathbf{z}$ could be obtained (Scheme 2).

(17) Helgen, C.; Bochet, C. G. J. Org. Chem. 2003, 68, 2483-2486.

(18) Carpino, L. A.; Beyermann, M.; Wenschuh, H.; Bienert, M. Acc. Chem. Res. 1996, 29, 268-274.

(19) Quéléver, G.; Burlet, S.; Garino, C.; Pietrancosta, N.; Laras, Y.; Kraus, J.-L. J. Comb. Chem. 2004, 6, 695-698.

(20) Crosignani, S.; Gonzalez, J.; Swinnen, D. Org. Lett. 2004, 6, 45794582 .

(21) Suzuki, H.; Tsuji, J.; Hiroi, Y.; Sato, N.; Osuka, A. Chem. Lett. 1983, $449-452$.

(22) Katritzky, A. R.; Suzuki, K.; Wang, Z. Synlett 2005, 11, 1656-1665.
The synthesis of phenylethylamine derivatives 4-7 was attempted from commercially available 2-methoxyphenethylamine (12, Scheme 3 ), but only $\mathbf{2}$ appears as a product with any yield to speak of (Scheme 3). After protection of the amine 12 with a trifluoroacetyl group, the aromatic part was doubly nitrated by electrophilic aromatic substitutions. Subsequent demethylation of the intermediate $\mathbf{1 4}$ with $\mathrm{LiCl}$ in $\mathrm{DMF}$ at reflux furnished phenol 15. This phenol was then converted to the corresponding aryl bromide 16, iodide 18, and triflate 17 (Scheme 4). When the trifluoroacetamide was removed under basic conditions $\left(\mathrm{K}_{2} \mathrm{CO}_{3}\right.$ in $\left.\mathrm{MeOH} / \mathrm{H}_{2} \mathrm{O}\right)$ to liberate the amines 5-7, DniH (2) was directly formed; unfortunately, a spontaneous cyclization occurred by intramolecular amine arylation without catalyst, clearly due to the strong electron-withdrawing character of the aromatic part. To circumvent that problem, the trifluoroacetyl protecting group was replaced by a Boc group, labile under acidic conditions. It was introduced on bromoaryl derivative 16 by reaction with di-tert-butyl dicarbonate and a catalytic amount of DMAP in acetonitrile at room temperature (Scheme 5). It was then removed with $\mathrm{HCl}$ in ethanol to form the stable amine hydrochloride salt 20.

As test substrate, Cbz- $L$-Leu-OH (1a) was coupled to amine hydrochloride salt $\mathbf{2 0}$ with isobutyl chloroformate (IBCF) and $N$-methylmorpholine (NMM), providing in $86 \%$ yield the acylated compound $\mathbf{9 a}$, which was subsequently submitted to an intramolecular Buchwald-Hartwig amidation ${ }^{24}$ under microwave irradiation, using 2-dicyclohexylphosphino-2'-methylbiphenyl (Me-Phos) as the ligand and $\mathrm{Pd}(\mathrm{dba})_{2}$ as the catalyst (Scheme 6). Thus, Cbz-L-Leu-Dni (3a) was obtained in high yield (94\%). Microwave heating was necessary to accelerate the reaction and to improve its efficiency. Initial experiments with either a copper catalyst ${ }^{25}$ or Xantphos (9,9-dimethyl-4,5bis(diphenylphosphino)xanthene) as a ligand and $\mathrm{Pd}_{2}(\mathrm{dba})_{3}$ as a palladium source ${ }^{26}$ or only a strong base like $\mathrm{NaH}$ and LDA did not afford the cyclization.

As shown in Table 1, various amino acids were tested, all of them giving good to excellent yields $(82-97 \%)$ for the acylation (step 1); on the other hand, different problems were observed for the intramolecular amide $N$-arylation (step 2). Indeed, the reaction conditions for the cyclization, using $\mathrm{K}_{2} \mathrm{CO}_{3}$, are not compatible with the Fmoc protecting group due to its cleavage in basic medium (entries 3 and 10). Moreover, a free alcohol group is not tolerated, as it results essentially in the formation of DniH (entry 6). On the other hand, its protection allowed satisfactory yields (>80\%) for that step (entries 7 and 13) to be attained. In the case of cysteine amino acids $1 \mathrm{k}$ and $1 \boldsymbol{l}$, where the thiol group is protected with the benzyl (Bzl) or acetoamidomethyl (Acm) group, respectively, no desired product was formed and essentially starting material was recovered (entries 11 and 12). We suspected initially that the sulfur atom on the cysteine might act as a poison to the catalyst, but strangely, methionine cyclized with an $80 \%$ yield (entry 9). Nevertheless, common amino acid protecting groups other than Fmoc, such as $\mathrm{Boc}, \mathrm{Cbz}$, and $\mathrm{O}^{t} \mathrm{Bu}$, are well tolerated under the current conditions.

The photolabile protecting group $\alpha, \alpha$-dimethyl-3,5-dimethoxybenzyloxycarbonyl (Ddz), ${ }^{27}$ available for the amine function and initially developed for peptide applications, was also tested in this two-step sequence (Table 2). All $N$-Ddz- $\alpha$-amino acids 1o-z gave good to excellent yields $(66-91 \%)$ in the coupling reaction (step 1). With regards to the intramolecular amine arylation (step 2), the yields were essentially similar (69-88\%), 
SCHEME 2. Alternative Pathway for the Synthesis of $N$-Protected- $\alpha$-Amino Acyl-5,7-dinitroindolines<smiles>[R]C(N[Pb]C)C(=O)N1CCc2cc([N+](=O)[O-])cc([N+](=O)[O-])c21</smiles>

SCHEME 3. Synthesis of Phenol 15

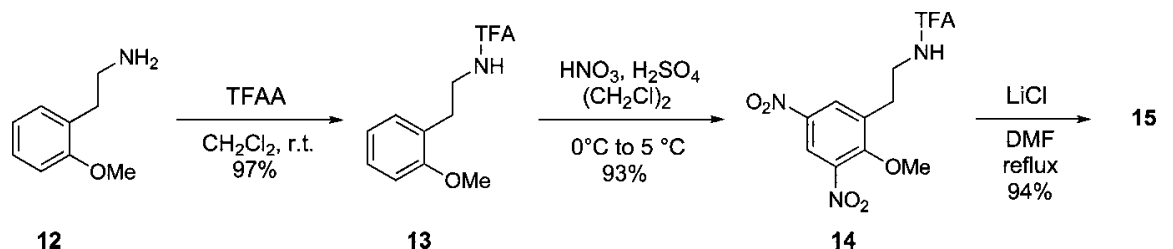

SCHEME 4. Unsuccessful Synthesis of Phenylethylamine Derivatives 4-7

$$
\underset{(0 \%)}{7}+\underset{(64 \%)}{2}
$$

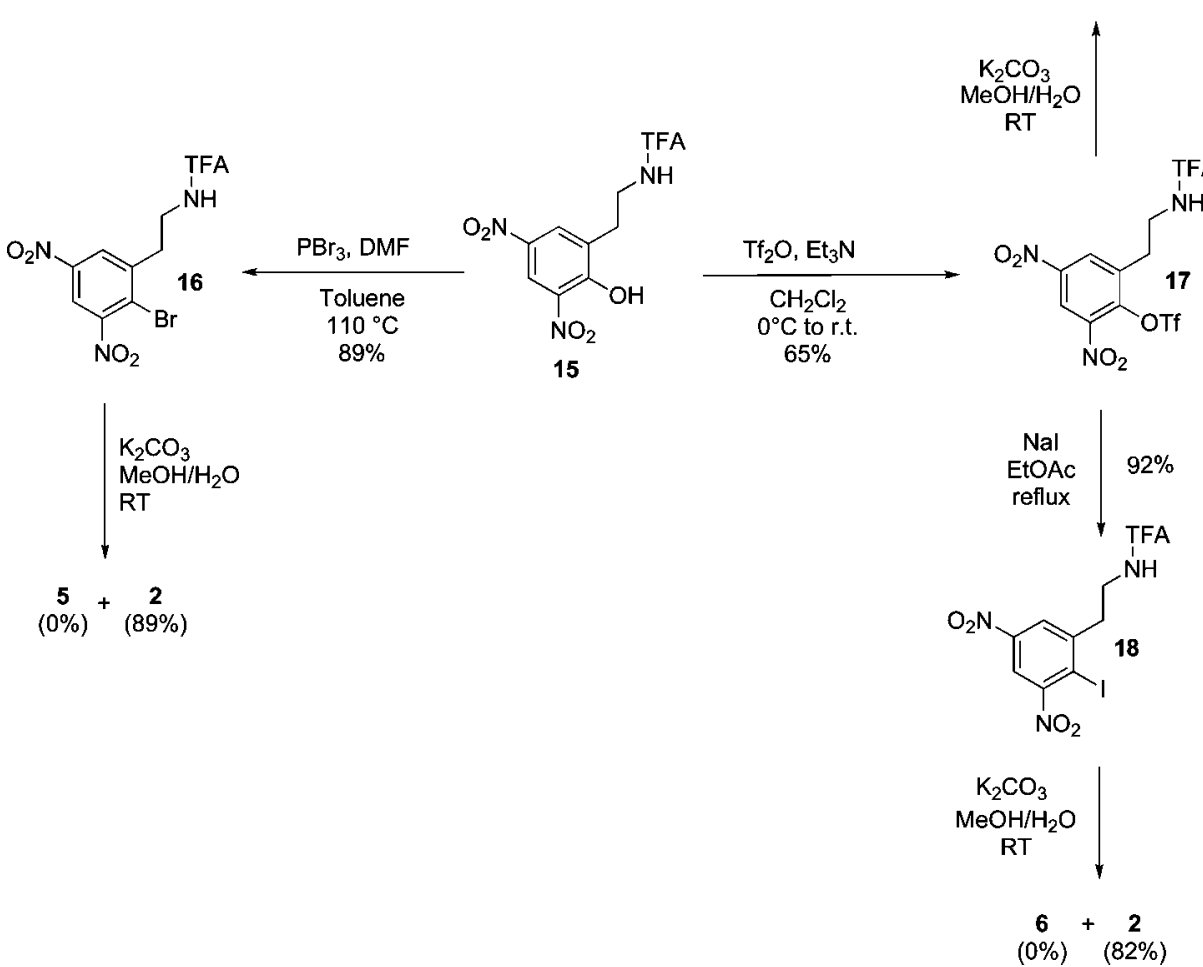

SCHEME 5. Successful Preparation of Amine Hydrochloride 20<smiles>O=[N+]([O-])c1cc(CCNC(F)F)c(Br)c([N+](=O)[O-])c1</smiles>

16

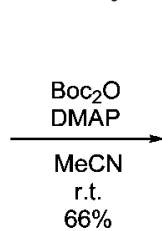

$66 \%$<smiles>O=C(NCCc1cc([N+](=O)[O-])cc([N+](=O)[O-])c1Br)c1ccccc1</smiles>

19<smiles>CC(Cl)[C@H](C)O[W](=O)(=O)c1cc(CCN)c(Br)c([N+](=O)[O-])c1</smiles>

20 except for the threonine derivative $\mathbf{1 x}$ (entry 10) where the yield was moderate (40\%). Extending the reaction time to $9 \mathrm{~h}$ led only to a slight increase of the yield (to $52 \%$ ), probably because of the surrounding steric bulk.
II. Preparation of $N$-Protected- $\alpha$-Amino Acid Amides by Photochemical Acylation. With these building blocks in hand, we checked their reactivity in the photoacylation reaction, using phenethylamine (21). Thus, $N$-protected- $\alpha$-amino acyl- 
SCHEME 6. Synthesis of $N$-Protected- $\alpha$-Amino Acyl-5,7-dinitroindolines 3a-z from 2-(2-Bromo-3,5-dinitrophenyl)ethanamine Hydrochloride (20)

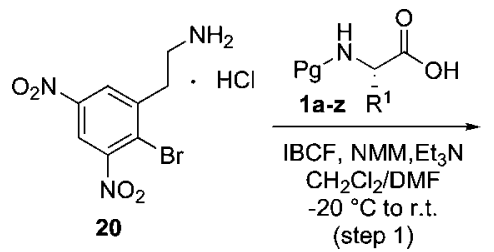

TABLE 1. Preparation of $N$-Boc, Cbz, and Fmoc- $\alpha$-Amino Acyl-5,7-dinitroindolines

\begin{tabular}{|c|c|c|c|c|}
\hline entry & $\begin{array}{l}\text { amino } \\
\text { acid }\end{array}$ & product & $\begin{array}{l}\text { yield }^{a, c} \\
(\%) \text { of } 9\end{array}$ & $\begin{array}{l}\text { yield }^{b, c} \\
(\%) \text { of } \mathbf{3}\end{array}$ \\
\hline 1 & Cbz-L-Leu-OH, 1a & Cbz-L-Leu-Dni, 3a & 86 & 94 \\
\hline 2 & Cbz- $L-\mathrm{Ala}-\mathrm{OH}, \mathbf{1 b}$ & Cbz- $L$-Ala-Dni, $\mathbf{3 b}$ & 94 & 84 \\
\hline 3 & Fmoc- $L-A l a-O H, 1 c$ & Fmoc-L-Ala-Dni, 3c & 92 & 0 \\
\hline 4 & Cbz- $L$-Pro-OH, $1 d$ & Cbz-L-Pro-Dni, 3d & $94^{d}$ & $88^{d}$ \\
\hline 5 & Boc- $L$-Phe-OH, 1e & Boc- $L$-Phe-Dni, 3e & 90 & 81 \\
\hline 6 & Boc- $L-S e r-O H, \mathbf{1 f}$ & Boc- $L$-Ser-Dni, $\mathbf{3 f}$ & 78 & 0 \\
\hline 7 & $\mathrm{Cbz}-L-\operatorname{Ser}\left({ }^{t} \mathrm{Bu}\right)-\mathrm{OH}, \mathbf{1 g}$ & $\mathrm{Cbz}-L-\operatorname{Ser}\left({ }^{t} \mathrm{Bu}\right)-\mathrm{Dni}, \mathbf{3 g}$ & 95 & 91 \\
\hline 8 & Boc- $L$-Val-OH, $\mathbf{1 h}$ & Boc- $L$-Val-Dni, $\mathbf{3 h}$ & 94 & 84 \\
\hline 9 & Boc- $L$-Met-OH, 1i & Boc- $L$-Met-Dni, 3i & 97 & 80 \\
\hline 10 & Fmoc- $L-$ Met-OH $\mathbf{1 j}$ & Fmoc- $L$-Met-Dni $\mathbf{3 j}$ & 82 & 0 \\
\hline 11 & Boc- $L-\mathrm{Cys}(\mathrm{Bzl})-\mathrm{OH}, \mathbf{1 k}$ & Boc-L-Cys(Bzl)-Dni, 3k & 92 & 0 \\
\hline 12 & Boc- $L$-Cys (Acm)-OH, $\mathbf{1} l$ & Boc- $L$-Cys(Acm)-OH, $3 l$ & 97 & 0 \\
\hline 13 & Boc- $L-\mathrm{Tyr}\left({ }^{t} \mathrm{Bu}\right)-\mathrm{OH}, \mathbf{1 m}$ & Boc- $L-\mathrm{Tyr}\left({ }^{t} \mathrm{Bu}\right)-\mathrm{Dni}, \mathbf{3 m}$ & 85 & 82 \\
\hline 14 & Boc- $L-$ Trp-OH, 1n & Boc- $L$-Trp-Dni, 3n & 95 & 80 \\
\hline
\end{tabular}

${ }^{a}$ General conditions: amino acid $(1.26 \mathrm{mmol})$, IBCF $(1.20 \mathrm{mmol})$, NMM $(1.20 \mathrm{mmol}), \mathrm{CH}_{2} \mathrm{Cl}_{2}(10 \mathrm{~mL}),-20{ }^{\circ} \mathrm{C}, 1 \mathrm{~h} ; 20(1.20 \mathrm{mmol})$, $\mathrm{Et}_{3} \mathrm{~N}(1.20 \mathrm{mmol})$, DMF $(5 \mathrm{~mL})$, room temperature, $4 \mathrm{~h} .{ }^{b}$ General conditions: intermediate $9 \mathbf{9}-\mathbf{n}(1 \mathrm{mmol}), \mathrm{Pd}(\mathrm{dba})_{2}(5 \mathrm{~mol} \%)$, Me-Phos $(5 \mathrm{~mol} \%), \mathrm{K}_{2} \mathrm{CO}_{3}$ (2 equiv), $\mathrm{Tol} / \mathrm{MeCN}=3: 1(20 \mathrm{~mL}), \mathrm{MW}, 100{ }^{\circ} \mathrm{C}$, 2 h. ${ }^{c}$ Isolated yield. ${ }^{d}$ Rotamers.

TABLE 2. Preparation of $N$-Ddz- $\alpha$-Amino Acyl-5,7-dinitroindolines

\begin{tabular}{|c|c|c|c|c|}
\hline entry & amino acid & Product & $\begin{array}{l}\text { yield }^{a, c}, \\
(\%) \text { of }\end{array}$ & $\begin{array}{c}\operatorname{yield}^{b, c} \\
(\%) \text { of } 3\end{array}$ \\
\hline 1 & Ddz- $L$-Gly-OH, 10 & Ddz-L-Gly-Dni, 30 & 77 & 76 \\
\hline 2 & Ddz-L-Ala-OH, 1p & Ddz-L-Ala-Dni, 3p & 94 & 78 \\
\hline 3 & Ddz-D-Ala-OH, 1q & Ddz-D-Ala-Dni, $\mathbf{3 q}$ & 91 & 88 \\
\hline 4 & Ddz- $L$-Leu-OH, 1r & Ddz-L-Leu-Dni, 3r & 92 & 88 \\
\hline 5 & Ddz-L-Phe-OH, 1s & Ddz-L-Phe-Dni, 3s & 91 & 69 \\
\hline 6 & Ddz-L-Trp-OH, 1t & Ddz-L-Trp-Dni, $3 \mathbf{t}$ & 87 & 77 \\
\hline 7 & Ddz-L-Pro-OH, $1 \mathbf{u}$ & Ddz- $L$-Pro-Dni, $3 \mathbf{u}$ & $77^{d}$ & $81^{d}$ \\
\hline 8 & Ddz- $L-T y r\left({ }^{t} \mathrm{Bu}\right)-\mathrm{OH}, \mathbf{1} \mathbf{v}$ & Ddz- $L-\operatorname{Tyr}\left({ }^{t} \mathrm{Bu}\right)-\mathrm{Dni}, \mathbf{3 v}$ & 80 & 72 \\
\hline 9 & $\operatorname{Ddz}-L-\operatorname{Ser}\left({ }^{t} \mathrm{Bu}\right)-\mathrm{OH}, \mathbf{1} \mathbf{w}$ & Ddz- $L-\operatorname{Ser}\left({ }^{t} \mathrm{Bu}\right)-\mathrm{Dni}, \mathbf{3 w}$ & 83 & 80 \\
\hline 10 & Ddz-L-Thr $\left({ }^{(} \mathrm{Bu}\right)-\mathrm{OH}, \mathbf{1} \mathbf{x}$ & Ddz- $L-\operatorname{Thr}\left({ }^{\prime} \mathrm{Bu}\right)-\mathrm{Dni}, \mathbf{3} \mathbf{x}$ & 66 & $40,52^{e}$ \\
\hline 11 & $\operatorname{Ddz}-L-\mathrm{Asp}\left(\mathrm{O}^{\prime} \mathrm{Bu}\right)-\mathrm{OH}, \mathbf{1}$ & $\operatorname{Ddz}-L-\operatorname{Asp}\left(\mathrm{O}^{t} \mathrm{Bu}\right)-\mathrm{Dni}, \mathbf{3 y}$ & 85 & 77 \\
\hline 12 & $\operatorname{Ddz}-L-\mathrm{Glu}\left(\mathrm{O}^{t} \mathrm{Bu}\right)-\mathrm{OH}, 1 \mathrm{z}$ & $\operatorname{Ddz}-L-G l u\left(\mathrm{O}^{t} \mathrm{Bu}\right)-\mathrm{Dni}, \mathbf{3 z}$ & 85 & 75 \\
\hline
\end{tabular}

${ }^{a}$ General conditions: amino acid $(1.26 \mathrm{mmol})$, IBCF $(1.20 \mathrm{mmol})$, NMM $(1.20 \mathrm{mmol}), \mathrm{CH}_{2} \mathrm{Cl}_{2}(10 \mathrm{~mL}),-20{ }^{\circ} \mathrm{C}, 1 \mathrm{~h} ; 20(1.20 \mathrm{mmol})$, $\mathrm{Et}_{3} \mathrm{~N}(1.20 \mathrm{mmol})$, DMF $(5 \mathrm{~mL})$, room temperature, $4 \mathrm{~h} .{ }^{b}$ General conditions: intermediate 9o-z $(1 \mathrm{mmol}), \mathrm{Pd}(\mathrm{dba})_{2}(5 \mathrm{~mol} \%)$, Me-Phos $(5 \mathrm{~mol} \%), \mathrm{K}_{2} \mathrm{CO}_{3}$ (2 equiv), $\mathrm{Tol} / \mathrm{MeCN}=3: 1(20 \mathrm{~mL}), \mathrm{MW}, 100{ }^{\circ} \mathrm{C}$, 2 h. ${ }^{c}$ Isolated yield. ${ }^{d}$ Rotamers. ${ }^{e}$ After $9 \mathrm{~h}$ of reaction.

5,7-dinitroindolines 3e,g,r were irradiated at $385 \mathrm{~nm}$ with 1 equiv of amine $\mathbf{2 1}$ in acetonitrile for $16 \mathrm{~h}$, affording the corresponding amides 22e,g,r in good yields (77-92\%) (Table 3 and Scheme 7). The Boc, Cbz, and Ddz amine protecting groups are compatible with these reaction conditions. It is interesting to note that the Ddz photolabile protecting group is stable at this operating wavelength $(385 \mathrm{~nm})$, i.e., it does not affect the yield of photoamidation (entry 3 ). This result adds

(23) For reviews, see: (a) Wolfe, J. P.; Wagaw, S.; Marcoux, J.-F.; Buchwald, S. L. Acc. Chem. Res. 1998, 31, 805-818. (b) Hartwig, J. F. Angew. Chem., Int. Ed. 1998, 37, 2046-2067.

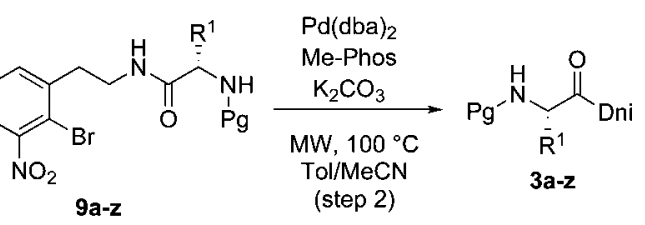

TABLE 3. Preparation of $N$-Protected- $\alpha$-Amino Acid Amides

\begin{tabular}{cllc}
\hline entry & \multicolumn{1}{c}{ reactant } & \multicolumn{1}{c}{$\mathrm{R}^{1}$} & yield $^{a}(\%)$ \\
\hline 1 & Boc- $L$-Phe-Dni, 3e & $\mathrm{PhCH}_{2}$ & 80 \\
2 & Cbz- $L$-Ser( $\left.{ }^{t} \mathrm{Bu}\right)-\mathrm{Dni}, \mathbf{3 g}$ & $\left(\mathrm{CH}_{3}\right)_{3} \mathrm{COCH}_{2}$ & 77 \\
3 & Ddz- $L$-Leu-Dni, 3r & $\left(\mathrm{CH}_{3}\right)_{2} \mathrm{CHCH}_{2}$ & 92 \\
${ }^{a}$ Isolated yield. & & \\
\hline
\end{tabular}

SCHEME 7. Photochemical Amidation with

$N$-Protected- $\alpha$-Amino Acyl-5,7-dinitroindolines

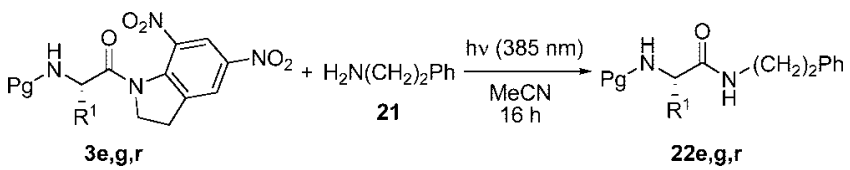

an attractive facet to our strategy of chromatic orthogonality. ${ }^{28}$ The experiments were carried out in quartz test tubes, using a LED-based photoreactor (Lumos 43), emphasizing the simplicity of this reaction.

III. Verification of the Stereochemical Integrity of the Amino Acids. To determine whether our conditions caused racemization of the amino acids during the two-step procedure and the photochemical reaction, we synthesized two diastereoisomers Ddz- $L$-Ala- $L$-Phe-O ${ }^{t} \mathrm{Bu}$ and Ddz- $D$-Ala- $L-\mathrm{Phe}-\mathrm{O}^{t} \mathrm{Bu}$ from commercially available and enantiomerically pure Ddz$L$-Ala-OH (1p) and Ddz-D-Ala-OH (1q), respectively. For the photochemical reaction, Ddz- $L$-Ala-Dni (3p) and Ddz- $D$-AlaDni (3q) were separately irradiated at $385 \mathrm{~nm}$ with $L$ phenylalanine tert-butyl ester hydrochloride $\left(L-\mathrm{Phe}-\mathrm{O}^{t} \mathrm{Bu} \cdot \mathrm{HCl}\right)$ in the presence of 1 equiv of $\mathrm{Et}_{3} \mathrm{~N}$ to furnish the two corresponding diastereoisomers, which were analyzed by ${ }^{1} \mathrm{H}$ NMR before and after column chromatographic purification. It showed no detectable racemization (i.e., <5\%). The methyl signal in the $L$-Ala- and the one in the $D$-Ala-diastereoisomer were well distinguishable by their different chemical shifts. In each spectrum, the absence of two separate doublets for the methyl protons corresponding to the $L L$ - and $D L$-diastereoisomers indicated that these reactions occurred with complete retention of chirality. The absence of racemization further confirms the absence of a ketene intermediate, in line with our previously reported mechanism. ${ }^{29}$

(24) (a) Bonnaterre, F.; Bois-Chaussy, M.; Zhu, J. Org. Lett. 2006, 8, 43514354

(25) Klapars, A.; Huang, X.; Buchwald, S. L. J. Am. Chem. Soc. 2002, 124, $7421-7428$.

(26) Yin, J.; Buchwald, S. L. J. Am. Chem. Soc. 2002, 124, 6043-6048.

(27) (a) Cameron, J. F.; Fréchet, J. M. J. J. Org. Chem. 1990, 55, 59195922. (b) Birr, C.; Lochinger, W.; Stahnke, G.; Lang, P. Liebigs Ann. Chem. 1972, 763, 162-172.

(28) (a) Blanc, A.; Bochet, C. G. J. Org. Chem. 2002, 67, 5567-5577. (b) Bochet, C. G. Angew. Chem., Int. Ed. 2001, 40, 2071-2073.

(29) Cohen, A. D.; Helgen, C.; Bochet, C. G.; Toscano, J. P. Org. Lett. 2005, 7, 2845-2848. 


\section{Conclusion}

We have described a methodology for the preparation of $N$-protected- $\alpha$-amino acyl-5,7-dinitroindolines $\mathbf{3 a}-\mathbf{x}$, and their utilization for photochemical acylation to synthesize $N$-protected$\alpha$-amino acid amides $\mathbf{2 2 e}, \mathbf{g}, \mathbf{r}$ under neutral conditions. The mild conditions, the simplicity, the operational ease, and the retention of the chirality offer advantages over conventional coupling techniques, and they could make this methodology a method of choice for the preparation of $N$-protected- $\alpha$-amino acid amides and peptides by photochemical acylation, thus avoiding the use of coupling reagents. It is, however, clear that this strategy remains appropriate for applications where scales remain modest and costs of building blocks are not crucial (i.e., for automated microscale synthesis).

\section{Experimental Section}

Preparation of 2-(2-Bromo-3,5-dinitrophenyl)ethanamine Hydrochloride (20). $N$-(2-Methoxyphenethyl)-2,2,2-trifluoroacetamide (13). Under argon, to a stirred solution of 2-methoxyphenetylamine (4.84 mL, $32.4 \mathrm{mmol})$ in dry $\mathrm{CH}_{2} \mathrm{Cl}_{2}(60 \mathrm{~mL})$ was added trifluoroacetic anhydride $(6.82 \mathrm{~mL}, 48.6 \mathrm{mmol})$ dropwise at around $5{ }^{\circ} \mathrm{C}$, over a period of $15 \mathrm{~min}$, with vigorous stirring. After the reaction mixture was stirred at $\mathrm{RT}$ for $1.75 \mathrm{~h}$, water $(60 \mathrm{~mL})$ and $\mathrm{CH}_{2} \mathrm{Cl}_{2}(60 \mathrm{~mL})$ were added. The organic layer was washed with water, separated, dried over $\mathrm{MgSO}_{4}$, and evaporated to give a colorless solid (7.745 g, 97\%). Mp 67-68 ${ }^{\circ} \mathrm{C} .{ }^{1} \mathrm{H}$ NMR $(360 \mathrm{MHz}$, $\left.\mathrm{CDCl}_{3}\right) \delta 7.26(\mathrm{t}, J=8.0 \mathrm{~Hz}, 1 \mathrm{H}), 7.20-7.13(2 \mathrm{H}), 6.93(\mathrm{~m}, 2 \mathrm{H})$, $3.86(\mathrm{~s}, 3 \mathrm{H}), 3.56(\mathrm{~m}, 2 \mathrm{H}), 2.92(\mathrm{t}, J=6.4 \mathrm{~Hz}, 2 \mathrm{H}) ;{ }^{13} \mathrm{C} \mathrm{NMR}$ $\left(90.55 \mathrm{MHz}, \mathrm{CDCl}_{3}\right) \delta$ 157.7-156.5 $\left(\mathbf{C}(\mathrm{O}) \mathrm{CF}_{3}\right), 157.1(\mathrm{C}), 130.7$, 128.4, 126.5, 121.1, 120.6-111.1 $\left(\mathrm{CF}_{3}\right), 110.4,55.1,41.0,29.2$. IR (neat) 3308, 3109, 2997, 1698, 1601, 1563, 1495, 1468, 1440, $1246,1201,1180,1123,1033,757$. HR-MS 270.0713 $\left(\mathrm{C}_{11} \mathrm{H}_{12} \mathrm{~F}_{3} \mathrm{NO}_{2}+\mathrm{Na}^{+}\right.$calcd 270.0712).

$N$-(2-Methoxy-3,5-dinitrophenethyl)-2,2,2-trifluoroacetamide (14). A solution of $N$-(2-methoxyphenethyl)-2,2,2-trifluoroacetamide (13) $(2.472 \mathrm{~g}, 10 \mathrm{mmol})$ in 1,2-dichloroethane $(10 \mathrm{~mL})$ was added dropwise over a period of $20 \mathrm{~min}$, with agitation and cooling using an ice bath, to a mixture of fuming nitric acid (100\%) $(2.49 \mathrm{~mL}$, $60 \mathrm{mmol}$ ) and sulfuric acid (96\%; $5.28 \mathrm{~mL}, 95 \mathrm{mmol}$ ) in 1,2-dichloroethane $(20 \mathrm{~mL})$, keeping the temperature of the solution below $5{ }^{\circ} \mathrm{C}$. The solution was stirred at 0 to $5{ }^{\circ} \mathrm{C}$ during $1 \mathrm{~h}$ and then quenched on ice. The product was extracted with $\mathrm{CH}_{2} \mathrm{Cl}_{2}$, washed with water, with saturated aq $\mathrm{NaHCO}_{3}$, then with water to neutrality, and finally with brine. The organic layer was dried with anhydrous $\mathrm{MgSO}_{4}$ and filtered, and then the solvents were evaporated under reduced pressure to give the desired product as a yellowish solid (3.135 g, 93\%). Mp 97-99 ${ }^{\circ} \mathrm{C} .{ }^{1} \mathrm{H}$ NMR $(360 \mathrm{MHz}$, DMSO- $\left.d_{6}\right) \delta 9.50(\mathrm{~m}, 1 \mathrm{H}), 8.67(\mathrm{~d}, J=2.7 \mathrm{~Hz}, 1 \mathrm{H}), 8.43(\mathrm{~d}, J=$ $2.7 \mathrm{~Hz}, 1 \mathrm{H}), 3.93$ (s, 3H), $3.50(\mathrm{~m}, 2 \mathrm{H}), 3.02(\mathrm{t}, J=6.8 \mathrm{~Hz}, 2 \mathrm{H})$; ${ }^{13} \mathrm{C}$ NMR $\left(90.55 \mathrm{MHz}, \mathrm{DMSO}-d_{6}\right) \delta 157.0-155.8\left(\mathbf{C}(\mathrm{O}) \mathrm{CF}_{3}\right)$, $156.2(\mathrm{C}), 142.9,142.0,136.6,129.7,120.6-111.1\left(\mathrm{CF}_{3}\right), 119.8$, 63.6, 62.7, 28.8. IR (neat) 3298, 1700, 1534, 1345, 1209, 1181, 983. HR-MS $360.0410\left(\mathrm{C}_{11} \mathrm{H}_{10} \mathrm{~F}_{3} \mathrm{~N}_{3} \mathrm{O}_{6}+\mathrm{Na}^{+}\right.$calcd 360.0414).

$\mathrm{N}$-(2-Hydroxy-3,5-dinitrophenethyl)-2,2,2-trifluoroacetamide (15). Under argon, $\mathrm{N}$-(2-methoxy-3,5-dinitrophenethyl)-2,2,2-trifluoroacetamide (14) $(1.180 \mathrm{~g}, 3.5 \mathrm{mmol})$ and $\mathrm{LiCl}(454 \mathrm{mg}, 10.5 \mathrm{mmol})$ were heated in boiling DMF (10 mL) during $2 \mathrm{~h}$. The solvent was then evaporated under reduced pressure and $1 \mathrm{M}$ aq $\mathrm{HCl}$ was added to the resulting mixture. The product was extracted with EtOAc and washed 3 times with water and with brine. The organic layer was dried with anhydrous $\mathrm{MgSO}_{4}$ and filtered, and then the solvents were evaporated under reduced pressure to give the desired product as a yellow solid $(1.059 \mathrm{~g}, 94 \%)$. Mp $133-136{ }^{\circ} \mathrm{C} .{ }^{1} \mathrm{H}$ NMR $(360$ MHz, DMSO- $\left.d_{6}\right) \delta 9.48$ (br, $\left.1 \mathrm{H}\right), 8.63(\mathrm{~d}, J=2.7 \mathrm{~Hz}, 1 \mathrm{H}), 8.27$ $(\mathrm{d}, J=2.3 \mathrm{~Hz}, 1 \mathrm{H}), 3.49(\mathrm{~m}, 2 \mathrm{H}), 2.67(\mathrm{t}, J=6.6 \mathrm{~Hz}, 2 \mathrm{H}) ;{ }^{13} \mathrm{C}$ NMR $\left(90.55 \mathrm{MHz}, \mathrm{DMSO}-d_{6}\right) \delta 157.0-155.8\left(\mathbf{C}(\mathrm{O}) \mathrm{CF}_{3}\right), 156.1$
(C), 138.0, 135.7, 131.9, 130.1, 120.7-111.2 ( $\left.\mathrm{CF}_{3}\right), 120.0,38.1$, 29.1. IR (neat) 3284, 3267, 3238, 3204, 3101, 1692, 1604, 1546, 1523, 1456, 1429, 1335, 1294, 1256, 1200, 1173, 1085, 701. HRMS 346.0257 $\left(\mathrm{C}_{10} \mathrm{H}_{8} \mathrm{~F}_{3} \mathrm{~N}_{3} \mathrm{O}_{6}+\mathrm{Na}^{+}\right.$calcd 346.0257).

$\mathrm{N}$-(2-Bromo-3,5-dinitrophenethyl)-2,2,2-trifluoroacetamide (16). Under argon, a solution of $N$-(2-hydroxy-3,5-dinitrophenethyl)2,2,2-trifluoroacetamide (15) $(0.220 \mathrm{~g}, 0.68 \mathrm{mmol}), \mathrm{PBr}_{3}(104 \mu \mathrm{L}$, $1.088 \mathrm{mmol})$, and DMF $(0.4 \mathrm{~mL}, 5.187 \mathrm{mmol})$ in toluene $(5 \mathrm{~mL})$ was stirred at $110^{\circ} \mathrm{C}$ during $1 \mathrm{~h}$. After addition of water and EtOAc, the product was extracted with EtOAc $(3 \times 20 \mathrm{~mL})$ and the combined organic layers were washed with water $(2 \times 10 \mathrm{~mL})$ and brine $(10 \mathrm{~mL})$, and then dried over anhydrous $\mathrm{MgSO}_{4}$, filtered, and concentrated under reduced pressure. Purification by flash column chromatography $\left[\mathrm{SiO}_{2}\right.$, hexane/EtOAc (1:1)] provided the desired product as a yellowish solid (234 mg, 89\%). Mp 155-156 ${ }^{\circ} \mathrm{C}$. ${ }^{1} \mathrm{H}$ NMR $\left(360 \mathrm{MHz}, \mathrm{DMSO}-d_{6}\right) \delta 9.53(\mathrm{br}, 1 \mathrm{H}), 8.81(\mathrm{~d}, J=$ $2.2 \mathrm{~Hz}, 1 \mathrm{H}), 8.42(\mathrm{~d}, J=2.3 \mathrm{~Hz}, 1 \mathrm{H}), 3.55(\mathrm{~m}, 2 \mathrm{H}), 3.20(\mathrm{t}, J=$ $6.6 \mathrm{~Hz}, 2 \mathrm{H}) ;{ }^{13} \mathrm{C}$ NMR $\left(125.0 \mathrm{MHz}, \mathrm{DMSO}-d_{6}\right) \delta 156.8-156.0$ $\left(\mathbf{C}(\mathrm{O}) \mathrm{CF}_{3}\right), 151.3,146.4,143.2,127.5,122.0,119.2-112.3\left(\mathrm{CF}_{3}\right)$, 118.0.0, 38.2, 34.7. IR (neat) 3298, 3087, 1696, 1558, 1537, 1460, 1348, 1211, 1174, 734. HR-MS $407.9421\left(\mathrm{C}_{10} \mathrm{H}_{7} \mathrm{BrF}_{3} \mathrm{~N}_{3} \mathrm{O}_{5}+\mathrm{Na}^{+}\right.$ calcd 407.9413).

2-(2-(2,2,2-Trifluoroacetamido)ethyl)-4,6-dinitrophenyl Trifluoromethanesulfonate (17). Under argon, a solution of $N$-(2-hydroxy3,5-dinitrophenethyl)-2,2,2-trifluoroacetamide (15) (0.323 g, 1.0 mmol) in anhydrous $\mathrm{CH}_{2} \mathrm{Cl}_{2}(10 \mathrm{~mL})$ was treated with $\mathrm{Et}_{3} \mathrm{~N}(0.364$ $\mathrm{mL}, 2.6 \mathrm{mmol})$, and the resulting solution was cooled in an ice-salt bath and treated dropwise with trifluoromethanesulfonic anhydride $(0.219 \mathrm{~mL}, 1.6 \mathrm{mmol})$. After that, the mixture was stirred at room temperature for $2 \mathrm{~h}, 0.5 \mathrm{~N} \mathrm{HCl}(10 \mathrm{~mL})$ was added in one portion, and the mixture was stirred for $30 \mathrm{~min}$. The aqueous layer was separated and extracted with $\mathrm{CH}_{2} \mathrm{Cl}_{2}(2 \times 20 \mathrm{~mL})$. The combined organic layers were washed with saturated $\mathrm{NaHCO}_{3}$, water, and brine, then dried over anhydrous $\mathrm{MgSO}_{4}$, filtered, and concentrated under reduced pressure. The residue was purified by column chromatography $\left[\mathrm{SiO}_{2}, \mathrm{CH}_{2} \mathrm{Cl}_{2}\right.$ then $\mathrm{EtOAc/hexane} \mathrm{(1:1)]} \mathrm{providing}$ the desired product as a yellow solid (296 mg, 65\%). ${ }^{1} \mathrm{H}$ NMR (360 $\left.\mathrm{MHz}, \mathrm{CDCl}_{3}\right) \delta 8.82(\mathrm{~d}, J=2.7 \mathrm{~Hz}, 1 \mathrm{H}), 8.55(\mathrm{~d}, J=2.7 \mathrm{~Hz}$, $1 \mathrm{H}), 6.56(\mathrm{br}, 1 \mathrm{H}), 3.78(\mathrm{~m}, 2 \mathrm{H}), 3.27(\mathrm{t}, J=6.8 \mathrm{~Hz}, 2 \mathrm{H}) ;{ }^{13} \mathrm{C}$ NMR (125.0 MHz, $\left.\mathrm{CDCl}_{3}\right) \delta$ 158.4-157.5 (C(O)CF $\left.)_{3}\right), 146.4$, 143.6, 142.4, 137.4, 130.2, 121.0, $119.7\left(\mathrm{CF}_{3}\right), 117.2\left(\mathrm{CF}_{3}\right), 39.3$, 30.4 .

$\mathrm{N}$-(2-Iodo-3,5-dinitrophenethyl)-2,2,2-trifluoroacetamide (18). A solution of 2-(2-(2,2,2-trifluoroacetamido)ethyl)-4,6-dinitrophenyl trifluoromethanesulfonate (17) (114 mg, $0.25 \mathrm{mmol})$ and $\mathrm{NaI}(0.129$, $0.85 \mathrm{mmol})$ in EtOAc $(5 \mathrm{~mL})$ was heated under reflux for $2 \mathrm{~h}$. After cooling to room temperature, the reaction mixture was washed with saturated $\mathrm{Na}_{2} \mathrm{~S}_{2} \mathrm{O}_{3}$ and brine, then dried over anhydrous $\mathrm{MgSO}_{4}$, filtered, and concentrated under reduced pressure. The residue was purified by column chromatography $\left[\mathrm{SiO}_{2}, \mathrm{CH}_{2} \mathrm{Cl}_{2}\right.$ then EtOAc/hexane (1:1)] providing the desired product as a yellow solid (99 mg, 92\%). ${ }^{1} \mathrm{H}$ NMR (360 MHz, DMSO- $\left.d_{6}\right) \delta 9.54(\mathrm{~m}, 1 \mathrm{H})$, $8.63(\mathrm{~d}, J=2.3 \mathrm{~Hz}, 1 \mathrm{H}), 8.28(\mathrm{~d}, J=2.3 \mathrm{~Hz}, 1 \mathrm{H}), 3.53(\mathrm{t}, J=6.4$ $\mathrm{Hz}, 2 \mathrm{H}), 3.22(\mathrm{t}, J=6.8 \mathrm{~Hz}, 2 \mathrm{H}) ;{ }^{13} \mathrm{C}$ NMR $(125.0 \mathrm{MHz}$, DMSO$\left.d_{6}\right) \delta 156.8-155.9\left(\mathbf{C}(\mathrm{O}) \mathrm{CF}_{3}\right), 156.0,147.2,147.0,125.7$, 119.2-112.4 $\left(\mathrm{CF}_{3}\right), 116.7,102.7,39.3,38.5$. HR-MS 455.9275 $\left(\mathrm{C}_{10} \mathrm{H}_{7} \mathrm{~F}_{3} \mathrm{IN}_{3} \mathrm{O}_{5}+\mathrm{Na}^{+}\right.$calcd 455.9275$)$.

tert-Butyl 2-Bromo-3,5-dinitrophenethylcarbamate (19). A solution of $N$-(2-bromo-3,5-dinitrophenethyl)-2,2,2-trifluoroacetamide (16) $(1.0 \mathrm{~g}, 2.59 \mathrm{mmol})$ and DMAP (97 $\mathrm{mg}, 0.777 \mathrm{mmol})$ in anhydrous $\mathrm{MeCN}(20 \mathrm{~mL})$ was stirred at room temperature under argon. A solution of di-tert-butyl dicarbonate $(0.750 \mathrm{~g}, 3.367 \mathrm{mmol})$ in anhydrous $\mathrm{MeCN}(5 \mathrm{~mL}$ ) was added dropwise and the reaction mixture was stirred at room temperature for $15 \mathrm{~h}$. The solvent was removed in vacuo and the product was purified by flash column chromatography $\left[\mathrm{SiO}_{2}\right.$, gradient hHexane/EtOAc (4:1) to hexane/ EtOAc $(3: 1)$ ] to provide the desired product as a yellowish solid (667 mg, 66\%). Mp $137{ }^{\circ} \mathrm{C} .{ }^{1} \mathrm{H}$ NMR (360 MHz, $\left.\mathrm{CDCl}_{3}\right) \delta 8.40$ $(\mathrm{d}, J=2.7 \mathrm{~Hz}, 1 \mathrm{H}), 8.28$ (d, $J=2.7 \mathrm{~Hz}, 1 \mathrm{H}), 4.68$ (br, 1H), 3.47 
$(\mathrm{m}, 2 \mathrm{H}), 3.22(\mathrm{t}, J=6.8 \mathrm{~Hz}, 2 \mathrm{H}), 1.41(\mathrm{~s}, 9 \mathrm{H}) ;{ }^{13} \mathrm{C} \mathrm{NMR}(90.55$ $\left.\mathrm{MHz}, \mathrm{CDCl}_{3}\right) \delta 155.9,151.5,146.5,144.5,127.5,123.1,118.2$, 80.1, 39.6, 37.4, $28.4(3 \times$ C). IR (neat) 3343, 1685, 1543, 1439, $1363,1344,1302,1274,1253,1163,1037,734,647$. HR-MS $412.0117\left(\mathrm{C}_{13} \mathrm{H}_{16} \mathrm{BrN}_{3} \mathrm{O}_{6}+\mathrm{Na}^{+}\right.$calcd 412.0115).

2-(2-Bromo-3,5-dinitrophenyl)ethanamine Hydrochloride (20). Under argon, tert-butyl 2-bromo-3,5-dinitrophenethylcarbamate (19) (340 mg, $0.87 \mathrm{mmol}$ ) was treated with $\mathrm{HCl}$ (1.25 M in EtOH, 20.9 $\mathrm{mL}, 26.1 \mathrm{mmol})$ then the mixture was stirred at room temperature for $16 \mathrm{~h}$. A colorless precipitate was formed during the reaction and then the solvent was evaporated under reduced pressure. The resulting solid was washed with EtOAc and filtrated to give the desired product as a yellowish solid (258 mg, 91\%). Mp 246-250 ${ }^{\circ} \mathrm{C}$ dec. ${ }^{1} \mathrm{H}$ NMR $\left(360 \mathrm{MHz}, \mathrm{D}_{2} \mathrm{O}\right) \delta 8.67(\mathrm{~d}, J=2.3 \mathrm{~Hz}, 1 \mathrm{H})$, $8.50(\mathrm{~d}, J=2.3 \mathrm{~Hz}, 1 \mathrm{H}), 3.42-3.32(4 \mathrm{H}) ;{ }^{13} \mathrm{C} \mathrm{NMR}(90.55 \mathrm{MHz}$, $\left.\mathrm{D}_{2} \mathrm{O}\right) \delta 151.3,146.9,141.8,128.4,123.6,119.9,38.4,34.1$. IR (KBr pastille) 3416, 3082, 2923, 1608, 1584, 1543, 1480, 1348, 1309, 1043, 738. HR-MS $289.9779\left(\mathrm{C}_{8} \mathrm{H}_{8} \mathrm{BrN}_{3} \mathrm{O}_{4}+\mathrm{H}^{+}\right.$calcd 289.9771).

General Procedure for the Preparation of $9 \mathbf{a}-\mathbf{z}$. Under argon, a solution of $N$-protected- $\alpha$-amino acids $(\mathbf{1 a}-\mathbf{z})(1.26 \mathrm{mmol})$ and $N$-methylmorpholine $(135 \mu \mathrm{L}, 1.20 \mathrm{mmol})$ in anhydrous DCM (10 $\mathrm{mL})$ at $-20{ }^{\circ} \mathrm{C}$ was treated with isobutylchloroformate $(159 \mu \mathrm{L}$, $1.20 \mathrm{mmol}$ ). After $1 \mathrm{~h}$, a solution of 2-(2-bromo-3,5-dinitrophenyl)ethanamine hydrochloride (20) $(392 \mathrm{mg}, 1.20 \mathrm{mmol})$ in anhydrous DMF $(5 \mathrm{~mL})$ was added dropwise and then, after $5 \mathrm{~min}$ of stirring, $\mathrm{Et}_{3} \mathrm{~N}(168 \mu \mathrm{L}, 1.20 \mathrm{mmol})$ was added dropwise to the solution. The reaction mixture was warmed to room temperature, stirred for $4 \mathrm{~h}$, and quenched with saturated $\mathrm{NaHCO}_{3}$ solution. The mixture was diluted with $\mathrm{CH}_{2} \mathrm{Cl}_{2}$ and the organic layer was washed with $1 \mathrm{M}$ aq $\mathrm{HCl}$, saturated aq $\mathrm{NaHCO}_{3}$ and brine, dried over $\mathrm{MgSO}_{4}$, filtered, and concentrated under reduced pressure. The residue was purified by flash column chromatography providing the desired product.

Benzyl (S)-1-(2-Bromo-3,5-dinitrophenethylcarbamoyl)-3-methylbutylcarbamate (9a). Purification was by flash column chromatography $\left[\mathrm{SiO}_{2}\right.$, hexane/EtOAc (1:1)] to give a slightly yellow solid (555 mg, 86\%). ${ }^{1} \mathrm{H}$ NMR (360 MHz, $\left.\mathrm{CDCl}_{3}\right) \delta 8.36(\mathrm{~d}, J=$ $2.3 \mathrm{~Hz}, 1 \mathrm{H}), 8.24(\mathrm{~d}, J=1.8 \mathrm{~Hz}, 1 \mathrm{H}), 7.37-7.29(5 \mathrm{H}), 6.43$ (br, $1 \mathrm{H}), 5.12-5.01(3 \mathrm{H}), 4.07(\mathrm{~m}, 1 \mathrm{H}), 3.58(\mathrm{~m}, 2 \mathrm{H}), 3.19(\mathrm{~m}, 2 \mathrm{H})$, $1.65-1.55(2 \mathrm{H}), 1.47(\mathrm{~m}, 1 \mathrm{H}), 0.90(\mathrm{t}, J=5.7 \mathrm{~Hz}, 6 \mathrm{H}) ;{ }^{13} \mathrm{C} \mathrm{NMR}$ $\left(125 \mathrm{MHz}, \mathrm{CDCl}_{3}\right) \delta 172.9,156.5,151.5,146.6,144.1,136.1,128.7$ $(2 \times C), 128.5,128.2(2 \times C), 127.6,122.9,118.3,67.4,53.7,40.9$, 38.5, 36.7, 24.8, 23.0, 22.0. IR (neat) 3315, 2957, 1693, 1652, 1542, 1348, 1265, 1232, 736. HR-MS $559.0800\left(\mathrm{C}_{22} \mathrm{H}_{25} \mathrm{BrN}_{4} \mathrm{O}_{7}+\mathrm{Na}^{+}\right.$ calcd 559.0799).

General Procedure for the Preparation of $N$-Protected- $\alpha$ Amino Acyl-5,7-dinitroindolines 3a,b, 3d,e, 3g-i, and 3m-z. A flame-dried vial was charged with intermediates $9 \mathbf{a}, \mathbf{b}, \mathbf{9 d}, \mathbf{e}, \mathbf{9 g}-\mathbf{i}$, and $9 \mathbf{m}-\mathbf{z}(1 \mathrm{mmol})$, MePhos (0.05 mmol, $5 \mathrm{~mol} \%), \mathrm{K}_{2} \mathrm{CO}_{3}(2$ $\mathrm{mmol})$, and $\mathrm{Pd}(\mathrm{dba})_{2}(0.05 \mathrm{mmol}, 5 \mathrm{~mol} \%)$. The vial was capped, evacuated, and backfilled with argon; this evacuation/backfill sequence was repeated two additional times. Anhydrous and deoxygenated (argon bubbling for $10 \mathrm{~min})$ toluene $(15 \mathrm{~mL})$ and
MeCN (5 mL) were then added through the septum. The sealed vial was then subjected to microwave heating $\left(100{ }^{\circ} \mathrm{C}\right)$ for $2 \mathrm{~h}$. After the reaction mixture was cooled to room temperature, the catalyst and salt were removed by filtration through a short pad of Celite and washed with EtOAc $(50 \mathrm{~mL})$. The filtrate was concentrated to dryness and purified by flash column chromatography to provide the desired product.

Benzyl (S)-4-Methyl-1-(5,7-dinitroindolin-1-yl)-1-oxopentan-2ylcarbamate (3a). Purification was by flash column chromatography $\left[\mathrm{SiO}_{2}\right.$, hexane/EtOAc (1:1)] to give a yellow solid (429 mg, 94\%). Mp $69{ }^{\circ} \mathrm{C} .{ }^{1} \mathrm{H}$ NMR $\left(360 \mathrm{MHz}, \mathrm{CDCl}_{3}\right) \delta 8.58(\mathrm{~s}, 1 \mathrm{H}), 8.27(\mathrm{~s}$, $1 \mathrm{H}), 7.35-7.27(5 \mathrm{H}), 5.35(\mathrm{~d}, J=8.7 \mathrm{~Hz}, 1 \mathrm{H}), 5.06(\mathrm{dd}, J=$ $19.5,12.2 \mathrm{~Hz}, 2 \mathrm{H}), 4.86(\mathrm{td}, J=10.0,3.6 \mathrm{~Hz}, 1 \mathrm{H}), 4.69$ (q, $J=$ $7.7 \mathrm{~Hz}, 1 \mathrm{H}), 4.33(\mathrm{q}, J=10.0 \mathrm{~Hz}, 1 \mathrm{H}), 3.51(\mathrm{~m}, 1 \mathrm{H}), 3.30(\mathrm{~m}$, $1 \mathrm{H}), 1.83(\mathrm{~m}, 1 \mathrm{H}), 1.63(\mathrm{t}, J=7.3 \mathrm{~Hz}, 2 \mathrm{H}), 1.01(\mathrm{t}, J=6.6 \mathrm{~Hz}$, $6 \mathrm{H}) ;{ }^{13} \mathrm{C}$ NMR $\left(125 \mathrm{MHz}, \mathrm{CDCl}_{3}\right) \delta 172.8,156.6,143.9,139.9$, 139.4, 138.8, 136.1, $128.7(2 \times \mathrm{C}), 128.4,128.0(2 \times \mathrm{C}), 123.4$, 119.9, 67.3, 52.1, 50.4, 41.4, 28.9, 24.7, 23.3, 22.0. IR (neat) 3405, 3326, 2961, 1699, 1609, 1545, 1466, 1441, 1396, 1373, 1341, 1282, 1256, 1217, 1047, 737. HR-MS 479.1534 $\left(\mathrm{C}_{22} \mathrm{H}_{24} \mathrm{~N}_{4} \mathrm{O}_{7}+\mathrm{Na}^{+}\right.$calcd 479.1537).

Typical Procedure for the Preparation of $N$-Protected- $\alpha$ Amino Acid Amides 22e,g,r by Photochemical Acylation. All experiments were performed in anhydrous acetonitrile (dried by passing it, under an argon atmosphere, through a Grubbs purification system). ${ }^{30}$ A mixture of $N$-protected- $\alpha$-amino acyl-5,7-dinitroindolines $(3 \mathbf{e}, \mathbf{g}, \mathbf{r})(0.10 \mathrm{mmol})$ and phenethylamine $(0.10 \mathrm{mmol}, 1$ equiv) in dry $\mathrm{MeCN}(2 \mathrm{~mL})$ was irradiated at $385 \mathrm{~nm}$ in a quartz tube for $16 \mathrm{~h}$, under an argon atmosphere, with vigorous stirring. The mixture was filtered, concentrated to dryness, and purified by flash column chromatography to provide the desired product.

tert-Butyl (S)-1-(Phenethylcarbamoyl)-2-phenylethylcarbamate (22e). Purification was by flash column chromatography $\left[\mathrm{SiO}_{2}\right.$, hexane/EtOAc (3:2)] to give a yellow solid (29.5 mg, 80\%). Mp $128-131{ }^{\circ} \mathrm{C} .{ }^{1} \mathrm{H}$ NMR $\left(360 \mathrm{MHz}, \mathrm{CDCl}_{3}\right) \delta 7.32-7.18(8 \mathrm{H}), 7.03$ $(\mathrm{d}, J=6.3 \mathrm{~Hz}, 2 \mathrm{H}), 5.69(\mathrm{br}, 1 \mathrm{H}), 5.02(\mathrm{br}, 1 \mathrm{H}), 4.24(\mathrm{~m}, 1 \mathrm{H})$, $3.41(\mathrm{~m}, 2 \mathrm{H}), 3.03(\mathrm{~m}, 2 \mathrm{H}), 2.64(\mathrm{~m}, 2 \mathrm{H}), 1.39$ (s, 9H); ${ }^{13} \mathrm{C} \mathrm{NMR}$ $\left(125 \mathrm{MHz}, \mathrm{CDCl}_{3}\right) \delta 171.1,155.4,138.7,136.9,129.5(4 \times \mathrm{C})$, $128.8(4 \times \mathrm{C}), 127.1,126.7,80.3,56.2,40.7,38.9,35.7,28.4(3$ $\times$ C). IR (neat) $3308,3021,2968,2923,1680,1647,1520,1442$, $1359,1289,1240,1161,739,691$. HR-MS $391.1991\left(\mathrm{C}_{22} \mathrm{H}_{28} \mathrm{~N}_{2} \mathrm{O}_{3}\right.$ $+\mathrm{Na}^{+}$calcd 391.1992).

Acknowledgment. We thank the Swiss National Science Foundation for their generous support (grant 620-066063).

Supporting Information Available: Procedures for preparing $3 \mathbf{b}-\mathbf{z}, \mathbf{9 b}-\mathbf{z}$, and $22 \mathbf{g}, \mathbf{r}$ and spectral data for $3 \mathbf{a}-\mathbf{z}, 9 \mathbf{a}-\mathbf{z}$, 13-20, and 22e,g,r.

(30) Pangborn, A. B.; Giardello, M. A.; Grubbs, R. H.; Rosen, R. K.; Timmers, F. J. Organometallics 1996, 15, 1518-1520. 